\title{
Assessment of Rice Variety Abhishek for Higher Yield and Income under Organic Farming of North Sikkim, India
}

\author{
Ambika Sharma $^{1^{*}}$ and T.T. Bhutia ${ }^{2}$ \\ ${ }^{1}$ SMS (Agronomy), Krishi Vigyan Kendra, Mangan, North Sikkim- 737 116, India \\ ${ }^{2}$ Krishi Vigyan Kendra, Mangan, North Sikkim- 737 116, India \\ *Corresponding author
}

A B S T R A C T

\begin{tabular}{|l|}
\hline K e y w o r d s \\
Abhishek variety, \\
Frontline \\
demonstration, \\
Organic, Rice, Sikkim \\
\hline Article Info \\
\hline $\begin{array}{l}\text { Accepted: } \\
\text { 04 February } 2018 \\
\text { Available Online: } \\
\text { 10 March 2018 }\end{array}$ \\
\hline
\end{tabular}

The KVK, Mangan, North Sikkim conducted On Station Trials and Frontline Demonstrations to evaluate the suitability and profitability of high yielding rice variety Abhishek over local variety Attey as check in different locations. Improved organic cultivation practices were followed for the Abhishek variety and traditional farmer practices for the local check variety. The results indicated that the yield increase of 46.34 to 51.72 percent in Abhishek variety was recorded over local variety. Highest yield of $37.70 \mathrm{qt} /$ ha with net return of Rs. 1,22,500 and C:B ratio of 2.85 could be obtained from the Abhishek variety in Ramthang village during 2017 season.

\section{Introduction}

The North eastern state of India, Sikkim is a tiny hilly state located at the foothills of the Himalayan range and is often referred as the 'Nature's Paradise' for its scenic beauty. Rice is the staple food grain in Sikkim next to maize grown exclusively during Kharif season. Bestowed with varied agro-climatic conditions, Sikkim produces some of the major crops such as cardamom, ginger, turmeric, off-seasons vegetables, flowers, kiwi, paddy, maize and millets. But the farmers of Sikkim are always inclined towards rice cultivation. The cultivation of rice has rather become like a tradition for the people and every year with the onset of monsoon marks the importance of rice cultivation for the Sikkimese people. A large number of landraces of rice both dry land and wetland were cultivated but almost all paddy landraces are now slowly disappearing due to lack of conservation methods, low productivity, lack of recent production technologies and so on.

The productivity of rice in Sikkim is at a very dismal figure of average $18.45 \mathrm{qt} / \mathrm{ha}$ (FS \& ADD, 2017). In order to meet the future food demands for the teeming population of the state, it is vital to give much emphasis on enhancing rice productivity. Most of the farmers are hesitant to take up rice cultivation 
as its total factor of productivity is declining and its profitability is in question with the rise in input costs. Modern crop management practices have been developed, but in most of the cases, farmers are not applying these technologies. There is certainly a gap between recommended and farmer's practices. This gap is responsible for the low productivity and lower returns. Hence new innovations and initiatives are required to make rice production system more sustainable and economically profitable. Under these circumstances, introduction of highly improved and high yielding varieties which performs well under organic management of Sikkim condition is one of the good options.

Keeping view upon this, Krishi Vigyan Kendra, Mangan, North Sikkim, had taken up Front Line Demonstration (FLD) to check the suitability of paddy variety that will be adaptable and profitable for the local farming community. Front Line Demonstration (FLD) is one of the extension methods to evaluate performance of technology under on-farm conditions, technology adoption by the participating farmers and its diffusion to nonparticipating farmers. These types of on-farm demonstration are so far the most effective extension methods (Chizari et al., 1999; Eke and Emah, 2001). In the present study, the Abhishek variety from CRRI, Cuttack was selected for assessment and performance over popular local variety Attey.

\section{Materials and Methods}

The present study was conducted by Krishi Vigyan Kendra, Mangan, North Sikkim, in the three villages (Gor, Taryeng and Ramthang) of Mangan district during Kharif season for three consecutive years of 2015, 2016 and 2017. A total of 60 numbers of front line demonstrations was conducted in theses three villages. Before Frontline Demonstration of this improve variety, successful On Station
Trial of paddy variety Abhishek was done first at North Sikkim KVK Farm to check its adaptability. System of Rice Intensification (SRI) and Organic Nutrient Management practices were followed for the Frontline Demonstration (FLD) of improved variety Abhishek. Popular farmer's variety Attey was used as the Local Check variety for the demonstration study. The other detail technologies interventions for the selected improve variety and farmer practices followed for check variety are given in Table 1 . Observations on different growth and yield parameters were taken and economic analysis was done by calculating cost of cultivation, gross return, net return and $\mathrm{B}$ : $\mathrm{C}$ ratio.

To Study the influence of the demonstrated technology, the percent increase in yield over farmers practice, the extension gap, technology gap and technology index were calculated using the following formula as suggested by Samui et al., (2000).

Extension gap $(\mathrm{qt} / \mathrm{ha})=$ Demonstration yield (qt/ha) - Yield of local check (qt/ha).

Technology gap $(q t / h a)=$ Potential yield (qt/ha) - Demonstration yield (qt/ha).

Technology index $(\%)=\{($ Potential yield Demonstration yield) / Potential yield $\}$ x 100

\section{Details of demonstration variety}

Abhishek is a high yielding rice variety released from Central Rice Research Institute (CRRI), Cuttack, Orissa. Unlike other varieties, with a gestation period of 135-140 days, this variety is ready for harvest by only 115-120 days. Even if there is delay in transplanting due to delay in harvest of previous crops or late release of water in the seasonal streams, the crop could be harvested with good yield. Such delay would have adverse effect on other varieties. Due to its 
early maturing character, its water requirement is also less, therefore can be grown even under rainfed condition.

\section{Results and Discussion}

\section{Effective tillers per plant, length of panicle and grains per panicle}

More number of filled panicles per plant (13), longer panicle $(18 \mathrm{~cm})$ and higher grains per panicle (185) were recorded in demonstrated variety Abhishek as compared to local farmer variety Attey (Table 2).

The differential response of the varieties could be attributed to its genetic potentiality and different packages of practices followed for the cultivation of demonstrated variety and farmer variety. These results are in agreement with those of Sarker et al., (2013).

Due to the improved organic scientific cultivation practices like seed treatment, green manure crop and organic manures applied in the demonstration field (Table 1), the soil fertility of demonstrated field might have improved than the farmer practices plot where no such application of organic manures was done. Depending upon the farming situation specific interventions may have greater implication in enhancing system productivity (Mukherjee, 2003).

\section{Paddy yield}

The results obtained (Table 3 ) indicated the percentage increased in the yield of the demonstrated variety over the farmer's local variety in all the three locations. The increased in the yield of demonstrated variety over the local variety was $46.34 \%$ at Gor, $46.66 \%$ at Taryeng and $51.72 \%$ at Ramthang village. Highest averaged grain yield of 37.70 quintal/ha was recorded in Ramthang village during 2017 Kharif season.
The difference in overall increment in the yield may be due to the overall improvement in plant growth characters like plant height, number of filled panicles per plant, panicle length and number of grain per panicle (Table 2) seen in the demonstrated variety. Similar results was reported by Kusutani et al., (2000) that the genotypes which produced higher number of grains per panicle also showed higher grain yield in rice.

\section{Extension and technology gap}

The extension and technology gap of 17.10, 16.80 and 19.50 quintal /ha and 13.10, 14.00 and 12.30 quintal/ha were recorded respectively at Gor, Taryeng and Ramthang village. More and more use of latest production technologies with high yielding varieties will subsequently change this alarming trend of galloping extension gap.

The front line demonstration was laid down under the supervision of Krishi Vigyan Kendra at the farmer's field, but still gap existed between the potential yield and demonstration yield. This may be attributed to dissimilarities in soil fertility, salinity, erratic rainfall and other vagaries of weather in the demonstrations area (Mitra and Samajdar, 2010).

Hence, variety wise location specific recommendation appears to be necessary to minimize the technology gap for yield level in different situations. Kadian et al., (1997) also reported that technology gap can be narrowed down only by location specific technology based recommendations.

\section{Technology index}

Technology index was recorded to be lowest during the last year of the study. The technology index varied from $28.00 \%$ to $24.60 \%$ with an average of $26.26 \%$. 
Table.1 Details of package of practices followed in the frontline demonstrations (FLDs)

\begin{tabular}{|c|c|c|c|}
\hline Sl.no. & Inputs & Demonstration & Farmers practice \\
\hline 1 & Paddy cultivar & Abhishek & Attey (Local) \\
\hline 2 & Spacing & $20 \mathrm{X} 15 \mathrm{~cm}$ & $25 \times 25 \mathrm{~cm}$ \\
\hline 3 & Seed treatment & Azospirrillum \& Phosphate Solubilizing Bacteria (PSB) @ 20gm/kg seed & $\begin{array}{l}\text { Azospirrillum \& Phosphate Solubilizing Bacteria (PSB) } \\
\text { @ 20gm/kg seed }\end{array}$ \\
\hline$\overline{4}$ & $\begin{array}{l}\text { Organic } \\
\text { application }\end{array}$ & $\begin{array}{l}\text { i. Buckwheat @ } 10-12 \mathrm{~kg} \text { seeds/acre was broadcasted as green manure which was ploughed back to } \\
\text { incorporate it to the soil after } 45 \text { days. } \\
\text { ii. FYM @ } 10-12 \mathrm{t} / \mathrm{ha} \text { and Vermicompost @ } 2 \mathrm{t} / \mathrm{ha} \text { at the time of final ploughing and puddling of the field. } \\
\text { iii. Inoculation of azolla @ } 500 \mathrm{~kg} / \mathrm{ha}, 10 \text { days after transplanting. }\end{array}$ & $\begin{array}{l}\text { FYM @ 10-12 t/ha and Vermicompost @ } 2 \mathrm{t} / \mathrm{ha} \text { at the time } \\
\text { of final ploughing and puddling of the field. }\end{array}$ \\
\hline
\end{tabular}

Table.2 Comparison of averaged yield attributes of rice between demonstration and local variety

\begin{tabular}{|l|c|c|}
\hline \multicolumn{1}{|c|}{ Characters } & Demonstration variety (Abhishek) & Local variety (Attey) \\
\hline Plant height $(\mathrm{cm})$ & 55 & 79 \\
\hline No. of filled panicles per plant & 13 & 6 \\
\hline Panicle length $(\mathrm{cm})$ & 18 & 17.7 \\
\hline No. of grains per panicle & 185 & 102 \\
\hline
\end{tabular}

Table.3 Yield, Technology gap, Extension gap and Technology Index of demonstration

\begin{tabular}{|c|c|c|c|c|c|c|c|c|c|}
\hline \multirow[t]{2}{*}{ Name of places } & \multirow[t]{2}{*}{ Years } & \multirow[t]{2}{*}{$\begin{array}{l}\text { No. of demons- } \\
\text { trations }\end{array}$} & \multirow{2}{*}{ 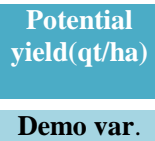 } & \multicolumn{2}{|c|}{$\begin{array}{c}\text { Average Yield } \\
\text { (qt/ha) }\end{array}$} & \multirow[t]{2}{*}{$\begin{array}{l}\text { Percent increase } \\
\text { over local }\end{array}$} & \multirow{2}{*}{$\begin{array}{c}\text { Techno - } \\
\text { logy gap } \\
\text { (qt/ha) }\end{array}$} & \multirow[t]{2}{*}{$\begin{array}{l}\text { Extension } \\
\text { gap (qt/ha) }\end{array}$} & \multirow[t]{2}{*}{$\begin{array}{l}\text { Techno -logy } \\
\text { Index (\%) }\end{array}$} \\
\hline & & & & Demo var. & Local var. & & & & \\
\hline Gor & 2015 & 15 & 50 & 36.90 & 19.80 & 46.34 & 13.10 & 17.10 & 26.20 \\
\hline Taryeng & 2016 & 13 & 50 & 36.00 & 19.20 & 46.66 & 14.00 & 16.80 & 28.00 \\
\hline Ramthang & 2017 & 32 & 50 & 37.70 & 18.20 & 51.72 & 12.30 & 19.50 & 24.60 \\
\hline Mean & - & - & 50 & 36.86 & 19.06 & 48.22 & 13.10 & 17.80 & 26.26 \\
\hline
\end{tabular}

Table.4 Economics

\begin{tabular}{|c|c|c|c|c|c|c|c|c|c|c|}
\hline \multirow[b]{2}{*}{ Years } & \multicolumn{2}{|c|}{ Grain yield (qt/ha) } & \multicolumn{2}{|c|}{ Cost of cultivation (Rs./ha) } & \multicolumn{2}{|c|}{ Gross return (Rs./ha) } & \multicolumn{2}{|c|}{ Net return (Rs./ha) } & \multicolumn{2}{|c|}{ B:C ratio } \\
\hline & Demo var. & Check var. & Demo var. & Check var. & Demo var. & Check var. & Demo var. & Check var. & Demo var. & Check var \\
\hline 2015 & 36.90 & 19.80 & $64,500.00$ & $52,500.00$ & $1,84,500.00$ & $99,000.00$ & $1,20,000.00$ & $46,500.00$ & 2.86 & 1.88 \\
\hline 2016 & 36.00 & 19.20 & $65,200.00$ & $53,000.00$ & $1,80,000.00$ & $96,000.00$ & $1,14,800.00$ & $43,000.00$ & 2.76 & 1.81 \\
\hline 2017 & 37.70 & 18.20 & $66,000.00$ & $54,000.00$ & $1,88,500.00$ & $91,000.00$ & $1,22,500.00$ & $37,000.00$ & 2.85 & 1.61 \\
\hline Mean & 36.86 & 19.06 & $65,233.33$ & $53,166.67$ & $1,84,333.33$ & $95,333.33$ & $1,19,100.00$ & $42,166.67$ & 2.82 & 1.76 \\
\hline
\end{tabular}


The decreased value of technology index in the last year of demonstration (24.60\%) during 2017 in Ramthang village reflected the feasibility of the improved package of practices for the farmers. The lower the values of technology index more will be the feasibility of the demonstration (Jeengar et al., 2006; Sager and Chandra, 2004).

\section{Economics}

The data on production economics (Table 4) clearly indicated the advantages of growing demonstration variety over the traditional local variety. The demonstrated variety recorded the higher averaged gross return of Rs 1,84,333 per ha and averaged additional net return of Rs. $1,19,100$ per ha over local check. Higher averaged B: C ratio of 2.82 was found in demonstrated variety due to higher net return as compared to local check. This could be due to high yielding of variety Abhishek and adoption of scientific production techniques. Similar results of adopting high yielding varieties and scientific methods by farmers in rice for higher economic return was reported by Sarada and Khurana (1993) and Nirmala and Muthuraman (2009).

\section{Acceptance by farmers}

The taste of the rice suits the local palate. Yield was significantly higher than the variety used by the farmers. Being impressed by the successful trials, the farmers are taking up the variety in large scale with the recommended management practices and increasing the area of cultivation under this variety.

From the present study, it can be concluded that demonstrations of present variety of paddy with scientific organic management technology can give promising results in terms of yield, extension gap and technology index. It was observed that yield contributing characters were higher in Abhishek variety. This technology had impacted not only on the adopting farmer but had also motivated neighbouring farmers and villages to take up this technology.

\section{References}

Annual Reports, (2017). Food Security \& Agriculture Development Department, Government of Sikkim.

Chizari, M., Lindner, J. R., and Lashkarara, F., (1999). Perception of Luristan Province, Iran Wheat Farmers with Respect to Sustainable Agricultural Practices. J. Int. Agril. Ext. Edn., 8: 6572.

Eke, A. G., and Emah, G. N., (2001). Assessment of Methods Training Farmers for the Implementation of Programmes of Agricultural Development Project in Rivers State of Nigeria. J. Ext. Sys., 17: 76-82.

Jeengar, K. L., Panwar, P., and Pareek, O. P., (2006). Frontline demonstration on maize in Bhilwara district of Rajasthan. Curr. Agric., 30: 115-16.

Kusutani, A., Tovata, M., Asanuma, K., and Kui, J., (2000). Studies on the varietal differences of harvest index and morphological characteristics of rice. Japanese J. Crop Sci., 69:359-364.

Mitra, B. and Samajdar, T., (2010). Field gap analysis of rapseed-mustard through front line demonstration. Agric. Exten. Rev., 22: 16-17.

Mukherjee, N., (2003). Participatory Learning and Action. Concept publishing company, New Delhi, India, pp. 63-65.

Nirmala B., and P. Muthuraman., (2009). Economic and constraint analysis of rice cultivation in Kaithal District of Haryana. Ind. Res. J. Ext. Edu., 9(1), 47-49.

Sagar, R. L., and Chandra, G., (2004). Frontline demonstration on sesame in 
West Bengal. Agril. Ext. Rev., 16: 7-10. Samui, S.K., Maitra, S., Roy, D.K.., Mandal, A.K., and Saha, D., (2000). Evaluation on front line demonstration on groundnut (Arachis hypogea L.). J. Indian Soc. Coastal Agric. Res., 18 (2): 180-183.

Sarada, M.K., and G.S., Khuran, (1993). Adoption gap and its model class in recommended rice technology. Indian journal of Extension Education., 29(1\&2):108-11

Sarker, C.B., Zahan, M., Majumdar, U.K., Islam, M.A., and Roy, B., (2013). Growth and yield potential of some local and high yielding boro rice cultivars. J. Agrofor. Environ, 7 (1): 107-110.

\section{How to cite this article:}

Ambika Sharma and Bhutia, T.T. 2018. Assessment of Rice Variety Abhishek for Higher Yield and Income under Organic Farming of North Sikkim, India. Int.J.Curr.Microbiol.App.Sci. 7(03): 410-415. doi: https://doi.org/10.20546/ijcmas.2018.703.048 